$9-1-2012$

\title{
How Does Stability in Financial Openness Affect Growth?
}

\author{
Erhan Aslanoglu \\ Marmara University \\ Pinar Deniz \\ Marmara University
}

Follow this and additional works at: https://ecommons.luc.edu/meea

Part of the Economics Commons

\section{Recommended Citation}

Aslanoglu, Erhan and Deniz, Pinar, "How Does Stability in Financial Openness Affect Growth?". Topics in Middle Eastern and North African Economies, electronic journal, 14, Middle East Economic Association and Loyola University Chicago, 2012, http://www.luc.edu/orgs/meea/

This Article is brought to you for free and open access by the Journals and Magazines at Loyola eCommons. It has been accepted for inclusion in Topics in Middle Eastern and North African Economies by an authorized administrator of Loyola eCommons. For more information, please contact ecommons@luc.edu. (C) 2012 the authors 


\title{
HOW DOES STABILITY IN FINANCIAL OPENNESS AFFECT GROWTH?
}

\author{
Erhan Aslanoğlu* \\ Marmara University \\ Pınar Deniz ${ }^{\dagger}$ \\ Marmara University
}

\begin{abstract}
In the growth process, financing is needed to fulfill the potential for growth. If there is an insufficiency, the potential is said to be underutilized. It is suggested that financial openness prevents the congestion when the real side of the economy is in need of finance. Therefore, the relief in accessing finance, in an indirect way, can contribute to economic growth.

Recently, there has been a growing literature analyzing whether the financial side has an impact on the real side of the economy. Within the financial side, a special attention is paid to international capital flows and whether they can have impact on economic growth. Some channels are described within the theory originating from financial openness to economic growth. However, there is a controversy for the causal link. Moreover, the link is criticized in the way that financial openness brings about exchange rate instability which further leads to destabilization in the real sector (Dornbusch, 1976). This study attempts to focus on domestically stable financial openness by considering financial openness and exchange rate stability together. Direct and indirect mechanisms are introduced. According to this, a new index is constructed to proxy stable financial openness via including portfolio investment plus exchange rate volatility. The new dataset is employed to analyze whether a domestically stable financial openness is able to affect the real side of the economy positively.
\end{abstract}

Keywords: Exchange Rate Volatility, Financial openness, Capital flows

JEL classification: F41, G15

\footnotetext{
*Marmara University, Turkey, Faculty of Economics and Administrative Sciences, Economics Department, e-mail: easlan@marmara.edu.tr

${ }^{\dagger}$ Marmara University, Turkey, EU Institute, e-mail: pinar.deniz@ marmara.edu.tr
} 


\section{INTRODUCTION}

In the growth process, financing is needed to fulfill the potential for growth. If there is a shortage, the potential is said to be underutilized. It is suggested that financial openness prevents the congestion when the real side of the economy is in need of finance. Therefore, the relief in accessing finance can contribute to economic growth.

There is a deep literature on financial openness and its impact on several variables such as economic growth. Within the financial side, a special attention is paid to international capital flows and whether they can have impact on economic growth. Financial openness is frequently presented as beneficial for the economy. Some channels are described within the theory originating from financial openness to economic growth. However, regarding direction and magnitude, there is a controversy for the relationship. Together with financial liberalization, a high level of capital will tend to flow in the economies that are attractive for the investors. Especially in emerging economies where charming elements are relatively higher than elsewhere, foreign investors may direct their funds to these countries. Financial openness may easily lead to some alterations in the domestic system. Likewise, without external effects, interest rates are determined domestically. However, external conditions will become effective when the matter is small economies. According to Bacchetta (1992) it is likely that after financial liberalization, first, capital inflows will be observed. Together with capital stock increase, domestic investments will be less and less charming as marginal productivity declines. This decline ends up with capital outflows. He explains that higher domestic interest rate lets foreign capital in and leads to appreciation first, but this is followed by capital outflow due to arbitration in foreign and domestic interest rates which further leads to depreciation of domestic currency.

Quinn and Toyoda (2008) argue that in analyzing the relationship between capital account liberalization and economic growth, differing time periods and collinearity among independent variables result in measurement errors. In this line, they employ both time series and cross sectional analysis and GMM analysis for a long time period of 1955-2004. They observe a positive relationship with economic growth independent of the country's economic development level. There are many other studies advocating the positive impact of financial openness (mainly using capital inflows dataset) on growth (Ferreira, 2009; Klein and Olivei, 
1999; Tornell et al., 2003; Haber, 1997). Bekaert et al. (2005) also finds that capital account liberalization contributes to economic growth. However, grounding on some studies (Rodrik, 1999), he states that openness is not completely appropriate for less developed economies since the domestic institutions and several other internal factors are not totally powerful in these economies. Yet they conclude that the countries with better conditions reflect relatively higher growth rates. In a similar manner, Choong et al. (2010), using a large number of developed and developing countries, observe that FDI reflects a positive effect on growth, whereas portfolio investment displays a negative impact for all countries in the dataset, but highlight that there is a specific threshold level for development in stock market above which can turn this negativity into positivity. Many other studies, as well, pay attention to the capacity of the host economy (Borensztein et al., 1998; Edwards, 2001; Rajan and Zingales, 1998).

Other than the capacity of the host economy, portfolio inflows may reflect a volatile character mainly for emerging economies (Ferreira, 2009). This volatility in portfolio investments is derived from the decisions, risk-return perceptions of the foreign investors. Moreover, financial openness may theoretically lead to exchange rate volatilities via the mechanism Bacchetta (1992) explains. There are also some empirical findings approving this claim. Employing a sample of 82 industrial and developing countries within the period 1975-2005, Calderon and Kubota (2009) show that financial openness strengthens real exchange rate (RER) volatility. Sutherland (1996), in a similar manner, observe a correlation between financial openness and RER volatility. However, exchange rate volatility is a problematic case for the economies since producers will become unable to see the future of external trade, whether they will be competitive or not in the international arena. In this manner, Dornbusch (1976) criticized the positive impact of financial openness on growth since financial openness brings about exchange rate instability which further leads to destabilization in the real sector.

This study attempts to focus on domestically stable financial openness by considering financial openness and exchange rate stability together. According to this, a new index is constructed to proxy stable financial openness via including portfolio investment plus exchange rate volatility. The new dataset is employed to analyze whether a domestically stable financial openness is able to affect the real side of the economy positively. The study analyzes the relationship between stability in openness and growth for emerging economies, 
namely as, China, Brazil, India, Indonesia, Korea, Mexico, Russia, Turkey and South Africa. Moreover, a developing country, the UK, is selected as a benchmark. The technique for empirical analysis is a causality investigation which is able to test causality under different frequencies.

The rest of the paper is organized as follows. Next section of the paper examines the transmission mechanism in details. Section 3 introduces the methodology and Section 4 presents the data and the dimension index employed. Section 5 discusses the empirical finding and last section concludes the paper shortly.

\section{TRANSMISSION MECHANISM}

In this paper, the scope is emerging markets, which are largely in need of finance compared to developed markets. Domestically insufficient savings leads to demand for foreign savings. Such high financial need, together with risk premium, keeps interest rates relatively higher. According to their risk perceptions, foreign investors decide whether to invest on these markets' financial instruments. Together with foreign portfolio inflows, emerging economies will be able reach the resource for investment.

The key point in emerging markets is that they are not saturated in the number of real sector firms. In other words, there are relatively less firms. Therefore, a small incentive ${ }^{1}$ has the capability to create a high motivation for new firms to enter the market. Likewise, Rajan and Zingales (1998) observes that together with financial development, growth in the number of new entries is higher in industries dependent on external finance. As mentioned in the literature part, there are many studies suggesting a positive impact of financial openness (and also financial development) on economic growth. There is also a theoretical background for such an impact which suggests that entrance to the market brings about an increase in growth under the neoclassical assumption of decreasing returns to scale for an individual firm, but constant returns to scale in the market as a whole.

An increase in portfolio investments may lead to appreciation in exchange rate for the host economy if the central bank does not carry out active exchange rate policy. Appreciation in

\footnotetext{
${ }^{1}$ The word "incentive" here refers to convenience in accessing resources and/or a decline in the cost of lending.
} 
exchange rate is an impediment for exports but it facilitates imports which will further work against economic growth. Secondly, if there is a volatility in exchange rate, portfolio investment inflows may perceive this as a risk signal and leave the host country which implies that the economy loses its financing for growth. Moreover, the firms will become unable to see the prospective international trade conditions which will negatively affect their investment incentives. Hence, appreciation or volatility seems to work against economic growth. On the other hand, if there is such an active exchange rate policy focusing on keeping exchange rate less volatile ${ }^{2}$, whatever the type of portfolio investments, either corporate security or money market, etc., direct and indirect mechanisms work which is suggested by this study as a distinct approach in the literature.

Assume that the central bank conducts exchange rate management policy aiming to keep exchange rate less volatile in addition to its price stability policy. As with foreign portfolio inflows, firms will be able to allay their need for financing. Considering the higher resources for investment ${ }^{3}$, the motivation of the new firms to enter the market with a little incentive (since the market is not saturated), and the stability in exchange rate, which enables firms to enter external trade more self-confidently, there will be a significant potential for growth. Increase in growth potential due to stability in exchange rate may be referred as a direct mechanism.

If there is an increase in portfolio investments, in order to prevent appreciation in exchange rate, central bank will apply open market operations (OMO) or buy foreign currency which will lead to increase in money supply and decrease in interest rate. As stated earlier, a small decline in interest rates is a crucial incentive for firms in need of cheaper domestic financing. With new entries to the real market, there will be an impetus for economic growth. Increase in growth potential due to decline in interest rates may be referred as indirect mechanism. Exchange rate stability is also a very crucial determinant of a country's external trade. Exchange rate appreciation resulting from foreign inflows leads to decline in economic

\footnotetext{
2 This may not only be a self-decision of the country. Rather it can be really applicable via the conditions demanded by EU. Keeping exchange rate within a specified boundary is applied in Maastricht criteria in order to be able to enter Euro zone (European Monetary Union).

${ }^{3}$ Higher resources may somehow imply a kind of development in financial system as the economy is able to get rid of the limits in domestic financing.
} 
growth as competitiveness is harmed. However, a stable exchange rate $^{4}$ (even rather than depreciation) enables the firms to see future more clearly and make investments more selfconfidently which will contribute to economic growth ${ }^{5}$. Hence, the suggestion of this study is that financial openness together with exchange rate stability turns out to create potential for growth. It may be argued that as with a decline in interest rate, there will be less portfolio investments. But this will probably not be the case since exchange rate volatility is relatively lower with an active central bank policy in exchange for a decline in interest rates. With a less volatile exchange rate, the risk premium of the foreign investors will be lower. Moreover, interest rates in emerging markets will still be relatively higher compared to developed economies which keeps emerging markets attractive for foreign investors. Accordingly, only relatively higher interest rates with a less risky environment will be more able to keep foreign inflows within these markets. Hence, portfolio investment inflow is a driving force for growth conditional on exchange rate stability.

Rajan and Zingales (2003) suggest that large firms are against new entrants since this will lead to decline in their profits together with ascending competition. However, financial development enhances competition as it facilitates new firms' entrance. Thereby, financial development is opposed by the "incumbent" firms. It is stressed that in an underdeveloped financial system, large firms have the privilege to access financing via their collateral and reputation and are able to hinder small firms from reaching financing. However, as with developments in the financial sector, such a mechanism is impaired. The authors emphasize that it is not likely that small domestic firms will be able to access foreign funds as the large incumbents may oppose this due to asymmetric information even if they do not need those foreign funds. However in our study, we suggest that a decline in interest rates ${ }^{6}$ due to stable exchange rate policy of the central bank, will create access to cheaper financing and therefore create a significant potential for small firms to be able to reach resources. Also, there will be a better condition for firms that aim external trade. The critical assumption here is that portfolio investments lead to a tendency for appreciation in exchange rate, otherwise, decline in interest rate via OMO etc. is invalid. Nevertheless, this is more than an assumption since the focus

\footnotetext{
${ }^{4}$ Reinhart and Rogoff (2002) state that among developing countries, due to "fear of floating", less volatility in exchange rate is more frequently mentioned.

5 Dornbusch (1976)

6 This time, the type of portfolio investments is devoted to money market, not corporate security since securities that foreign investors are able to reach, will belong to large incumbent firms.
} 
point is emerging economies which are known to receive very high foreign inflows as the return for investment ${ }^{7}$ is generally relatively higher than any other countries. Hence, it is already observed that the high foreign inflows tend to appreciate host economy's currency.

The mechanism mentioned in our study suggests an impact on economic growth. The impetus on growth is conditional on (i) the host economy's being able to attract foreign funds, and (ii) central bank of the host economy's exchange rate stability policy. This is modeled by utilizing two variables and turning them into a single index, which we refer as stability in openness index (SIO). SIO is composed of portfolio investment inflows and exchange rate volatility (monthly standard deviation of daily exchange rate).

\section{METHODOLOGY}

\subsection{Causality Tests in Time and Frequency Domain}

The Granger causality tests indicate whether the past changes in $\mathrm{x}(\mathrm{y})$ have an impact on current changes in $\mathrm{y}(\mathrm{x})$ over a specified time period. These types of analyses provide outcomes on causality over all frequencies. On the other hand, Geweke's linear measure of feedback from one variable to another at a given frequency provides detailed information about feedback relationships between two variables over different frequency bands. Even though frequency decompositions are generally investigated for neurophysiologic studies, it is important to address how causality changes with frequency. Besides, studies such as Y1ldirım and Taştan (2009) show that the significance and/or direction of the Granger causality tests in time domain can change after adopting the causality tests in frequency domain.

By using a Fourier transformation to VAR (p) model for $\mathrm{x}$ and $\mathrm{y}$ series, the Geweke's measure of linear feedback from $\mathrm{y}$ to $\mathrm{x}$ at frequency $\omega$ is defined as ${ }^{8}$ :

$M_{y \rightarrow x}(\omega)=\log \left[\frac{2 \pi f_{x}(\omega)}{\left|\psi_{11}\left(e^{-i \omega}\right)\right|^{2}}\right]=\log \left|1+\frac{\left|\psi_{12}\left(e^{-i \omega}\right)\right|^{2}}{\left|\psi_{11}\left(e^{-i \omega}\right)\right|^{2}}\right|$

\footnotetext{
${ }^{7}$ The risk is also calculated by the investors.

${ }^{8}$ For details of the computation of the measure, see Geweke (1982) and Breitung and Candelon (2006).
} 
If $\left|\psi_{12}\left(e^{-i \omega}\right)\right|^{2}=0$, then the Geweke's measure will be zero, then $\mathrm{y}$ will not Granger cause $\mathrm{x}$ at frequency $\omega$. Breitung and Candelon (2006) present this test by reformulating the relationship between $\mathrm{x}$ and $\mathrm{y}$ in VAR equation:

$$
x_{t}=\alpha_{1} x_{t-1}+\ldots \ldots .+\alpha_{p} x_{t-p}+\beta_{1} y_{t-1}+\ldots \ldots .+\beta_{p} y_{t-p}+\varepsilon_{1 t}
$$

The null hypothesis tested by Geweke, $M_{y \rightarrow x}(\omega)=0$, corresponds to the null hypothesis of $H_{0}: R(\omega) \beta=0$

where $\beta$ is the vector of the coefficients of $y$ and

$$
R(\omega)=\left[\begin{array}{l}
\cos (\omega) \cos (2 \omega) \ldots \ldots \ldots . \cos (p \omega) \\
\sin (\omega) \sin (2 \omega) \ldots \ldots \ldots . . . \sin (p \omega)
\end{array}\right]
$$

Breitung and Candelon (2006) simplify Geweke's null hypothesis so that a usual F-statistics can be used to test causality in frequency domain. Therefore, this study uses Breitung and Candelon (2006) version of Geweke (1982).

\section{DATA}

Monthly data is employed for China, Brazil, India, Indonesia, Korea, Mexico, Russia, Turkey and South Africa for the period 2000 - 2010. Daily exchange rate (to US dollar) obtained from FXTOP website ${ }^{9}$ is used to calculate monthly exchange rate volatility via standard deviation for each month.

Since taking into account of developing countries' exchange rate volatility will be misleading, a benchmark of a developed country is specified in order to incorporate the differentiation among developed and developing economies. UK is chosen as the benchmark.

Portfolio Investment Liabilities ${ }^{10}$ and Gross Domestic Product (both in US dollar currency) are employed from International Financial Statistics (IFS). Ratio of portfolio investment to GDP is quarterly data and interpolated to monthly data via constant match average. Industrial

\footnotetext{
${ }^{9}$ http://fxtop.com, Accessed: 20 April 2011.

${ }^{10}$ Portfolio investment liabilities include transactions with nonresidents in financial securities of any maturity (such as corporate securities, bonds, notes, and money market instruments) other than those included in direct investment, exceptional financing, and reserve assets.
} 
production (IP) index data is monthly obtained from OECD statistics. IP index is seasonally adjusted.

\subsection{DIMENSION INDEX}

Ratio of portfolio investment liabilities to Gross Domestic Product is used as a measure for openness. Exchange rate volatility is used in order to determine whether openness is stable or not. Hence, an index is created to observe stability in openness (SIO index). If there is openness, i.e., portfolio investment inflow is high, but there is also high exchange rate volatility, SIO index will not reveal a significant increase (depending on the magnitude of these two variables). In the same way, if there is a decline in financial openness but exchange rate volatility also reflects a decline, SIO index will not reveal a significant decline (depending on the magnitude of these two variables).

In order to create an index for stability in financial openness (SIO), dimension index methodology employed in human development index (HDI $)^{11}$ is utilized:

Dimension index: $\frac{\text { actual value - min value }}{\text { max value-min value }}$

According to the HDI calculation methodology, dimension indices are calculated for each variable that are included in HDI. Accordingly, if we are to construct an index for stability in financial openness, we have to construct dimension indices for each variable that takes part in the index, i.e., ratio of portfolio investment to GDP and exchange rate volatility. As mentioned in the data section, UK is used as a benchmark, otherwise maximum and minimum values for emerging economies will be chosen from themselves which will be highly deceptive. For example, in order to calculate dimension index for portfolio investment, we find maximum and minimum values among all nine economies (since UK is included) and for each country and time series data, minimum value is subtracted and then divided by the difference between maximum and minimum values. Hence, for each country, we obtain a dimension index for portfolio investment. The same calculation is done for exchange rate volatility and we obtain a dimension index for exchange rate volatility.

\footnotetext{
${ }^{11}$ http://hdr.undp.org/en/statistics/indices, Accessed: 27 March 2011.
} 
In HDI methodology, geometric mean of the relevant dimension indices is calculated, such as $\mathrm{HDI}=\mathrm{X}^{1 / 3} \mathrm{Y}^{1 / 3} \mathrm{Z}^{1 / 3}$, therefore a composite index is constructed. In SIO index, a composite index originating from exchange rate volatility index (XR VOL) and portfolio investment index (PORT) will be constructed. However, in SIO index, portfolio investment moves on the positive direction with SIO, whereas exchange rate volatility moves on the reverse direction. Therefore, the weight of exchange rate volatility index needs to be negative. In other words, a decline in exchange rate volatility will have a positive contribution to SIO index.

$\mathrm{SIO}=(\mathrm{PORT})^{1 / 2}(\mathrm{FX} \mathrm{VOL})^{-1 / 2}$

\section{EMPIRICAL FINDINGS}

In frequency domain analysis, the variables should be stationary. Hence, unit root test is employed for each variable of each country. The scope of our analysis is to observe the causal link between growth and openness. Industrial production is chosen as a proxy for economic level. Taking percentage change of IP index, not only a stationary serie is obtained, but also a proxy for economic growth rather than economic level. From Table 1, it is observed that both percentage change in industrial production index and stability in financial openness index are stationary since $\mathrm{p}$ values are lower than $5 \%$ significance level.

Frequency domain analysis from Figure 3 to 11 and Table 2 reflect that Brazil, China, Indonesia, Korea, Mexico, Turkey and South Africa data are in line with the theoretical mechanism this study suggests. These economies display a strong feedback from SIO index to growth at low frequencies with periodicities higher than 18 months. This indicates a long run causal link from SIO to growth. Russia, differently from the rest, reflects only short run causal link from SIO to growth. From growth towards SIO index, there is no causality at any frequency for these economies. India, given in Figure 5, shows that there is no causality from SIO index to growth since the critical value of 5.99 is overbounded. 


\section{CONCLUSION}

This study suggests that stability in openness has a positive impact on economic growth. The impetus on growth is conditional on economy's ability attract foreign funds and exchange rate stability. A new index is constructed using portfolio investment and exchange rate volatility variables which we refer as stability in openness index (SIO). Empirical findings reflect that all economies except for India show causality from SIO to growth. Among them, only Russia reflects a short run relationship; the rest reflects a long run relationship. Existence of a causal link indicates that financial openness with relatively stable FX contributes to growth. Eight out of nine emerging countries reflect an expected situation since these economies receive very large amounts of portfolio investments which create a potential and incentive for growth if exchange rate reflects a nearly stable movement. China and India stand out from of the other emerging economies together with their considerably high growth rates. Very high labor force together with low wages brings about crucial advantage in growth for these economies. Moreover China reflects another special situation of a very low FX volatility. It may be argued that low FX volatility and therefore the peaceful export conditions contributes to growth which shows itself with a long run and short run causal link between SIO and growth.

Concludingly, it may be argued that financial openness together with less volatility in exchange rate presents the opportunity to grow for emerging economies. As Corden (2002) highlighted, flexible exchange rate regime turns out to create high oscillations, in addition to that it is quite probable that fixed or currency board systems may end up with a crisis since they are very much exposed to external effects. At this point, managed floating exchange rate system may be a reasonable policy decision for the emerging economies. However, it is up to the real sector in these economies whether they will grow or not. As a further research, the number of countries in dimension index will be increased in order to enhance the dataset and obtain robust results. Pesaran et al. (2001) bounds test statistics may also be added in order to obtain the relevant magnitudes. 


\section{References}

Bacchetta, P., 1992. "Liberalization of Capital Movements and of the Domestic Financial System”, Economica, New Series, Vol. 59, No. 236, pp. 465-474.

Bekaert, G., Harvey, C.R., and Lundblad, C., 2005. "Does financial liberalization spur growth?”, Journal of Financial Economics, Vol. 77, pp. 3-55

Borensztein, E., De Gregorio, J., Lee, J.-W., 1998. "How does foreign direct investment affect economic growth?", Journal of International Economics, Vol. 45, pp.115-135.

Breitung, J., Candelon, B., 2006. "Testing for Short and Long-run Causality: A Frequency Domain Approach", Journal of Econometrics, 132, 363-378.

Calderón, C. And Kubota, M., 2009. ’Does Higher Openness Cause More Real Exchange Rate Volatility?", The World Bank Policy Research Working Paper, No. 4896.

Choong, C.-K., Baharumshah, A.Z., Yusop, Z. and Habibulla, M.S., 2010. "Private capital flows, stock market and economic growth in developed and developing countries: A comparative analysis", Japan and the World Economy, Vol. 22, pp. 107-117.

Corden, W. M., 2002. Too Sensational: On the Choice of Exchange Rate Systems, The MIT Press.

Dickey, D. A., Fuller, W. A., 1979. "Distribution of the Estimators for Autoregressive Time Series with a Unit Root", Journal of the American Statistical Association, Vol. 74, pp. 427431.

Dickey, D. A., Fuller, W. A., 1981. "The Likelihood Ratio Statistics for Autoregressive Time Series with a Unit Root", Econometrica, Vol. 49, pp. 1057-1072.

Dornbusch, R., 1976. "Expectations and Exchange Rate Dynamics" Journal of Political Economy, Vol. 84, pp. 1161-1176.

Edwards, S., 2001. "Capital mobility and economic performance: are emerging economies different”. In: Siebert, H. (Ed.), The World's New Financial Landscape: Challenges for Economic Policy. Springer, Berlin, pp. 219-244.

Granger, C. W. J., 1981. "Some Properties of Time Series Data and their Use in Econometric Model Specification”, Journal of Econometrics, Vol. 9, pp. 121-30.

Haber, S., 1997. "Financial markets and industrial development. A comparative study of government regulation, financial innovation, and industrial structure in Brazil and Mexico", 1840-1930. In: Haber, S. (Ed.), How Latin America Fell Behind: Essays on the Economic Histories of Brazil and Mexico. Stanford University Press, Stanford, CA, pp. 1800-1914.

Henry, P.B., 2007. "Capital account liberalization: Theory, evidence and speculation", Journal of Economic Literature, Vol. 45, pp. 887-935. 
Klein, M., Olivei, G., 1999. "Capital account liberalization, financial depth and economic Growth", Federal Reserve Bank of Boston Working Paper.

Kose, M.A., Prasad, E.S. and Terrones, M.E., 2009. "Does openness to international financial flows raise productivity growth?", Journal of International Money and Finance, Vol. 28, pp. 554-580.

Pesaran, M. H., Shin, Y., Smith, R. J., 2001. "Bounds Testing Approaches to the Analysis of Level Relationships”, Journal of Applied Econometrics, Vol. 16, pp. 289-326.

Quinn, D. P. and Toyoda, A. M. 2008. "Does Capital Account Liberalization Lead to Growth?", The Review of Financial Studies, Vol. 21, No. 3, pp. 1403-1449.

Rajan, R., Zingales, L., 1998. "Financial dependence and growth". The American Economic Review, Vol. 88, pp. 559-586.

Rodrik, D., 1999. The New Global Economy and Developing Countries: Making Openness Work, Overseas Development Council, Washington, DC.

Sutherland, A., 1996. "Financial Market Integration and Macroeconomic Volatility", Scandinavian Journal of Economics, Vol. 98, No. 4, pp. 521-539.

Tornell, A., Westermann, F. and Martínez, L., 2003. "Liberalization, Growth, and Financial Crises: Lessons from Mexico and the Developing World", Brookings Papers on Economic Activity, Vol. 2003, No. 2, pp. 1-88.

Yıldırım, N., Taştan, H., 2009. "Capital Flows and Economic Growth across Spectral Frequencies: Evidence from Turkey", Turkish Economic Association Working Paper Series No. 2009/2, Ankara. 


\section{APPENDIX}

Figure 1: INDUSTRIAL PRODUCTION INDEX (seasonally adjusted)

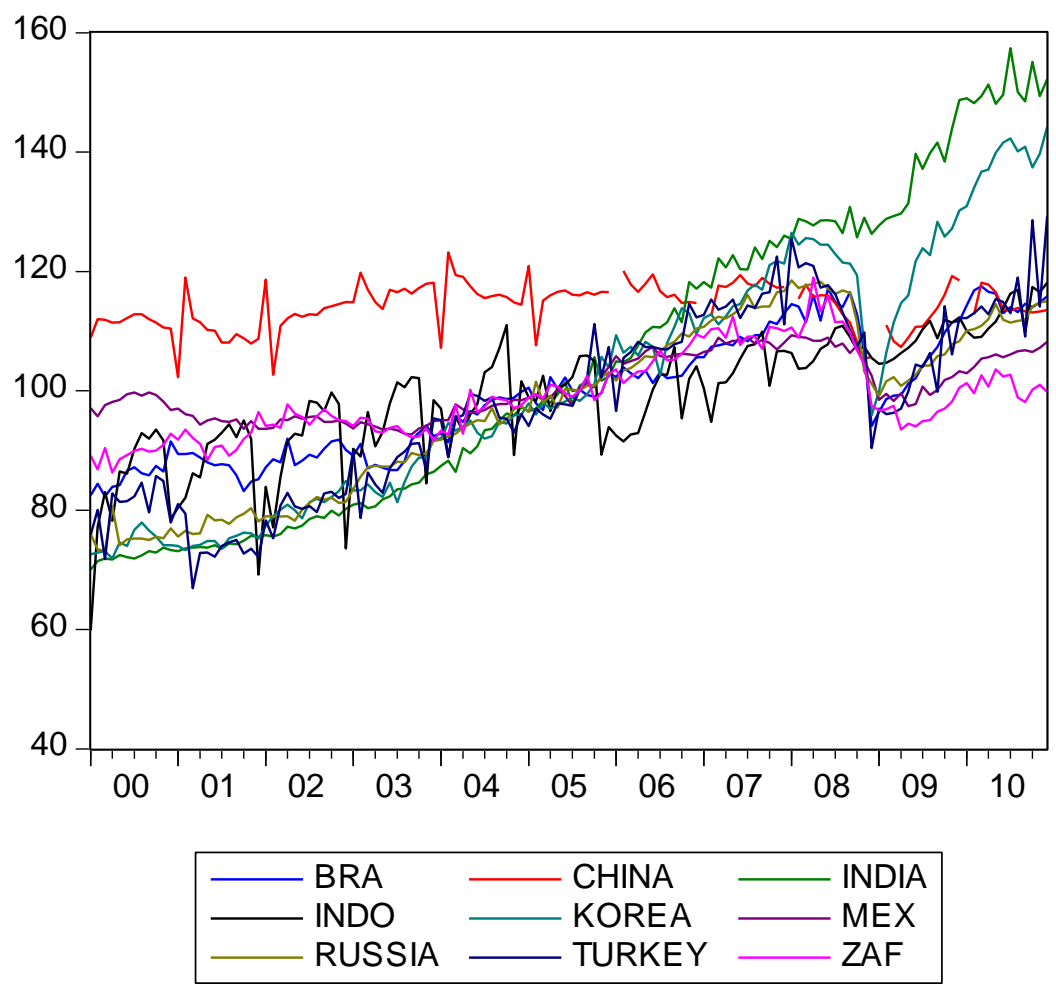

Figure 2: DAILY EXCHANGE RATE (normalized base to 100 with the initial date) 


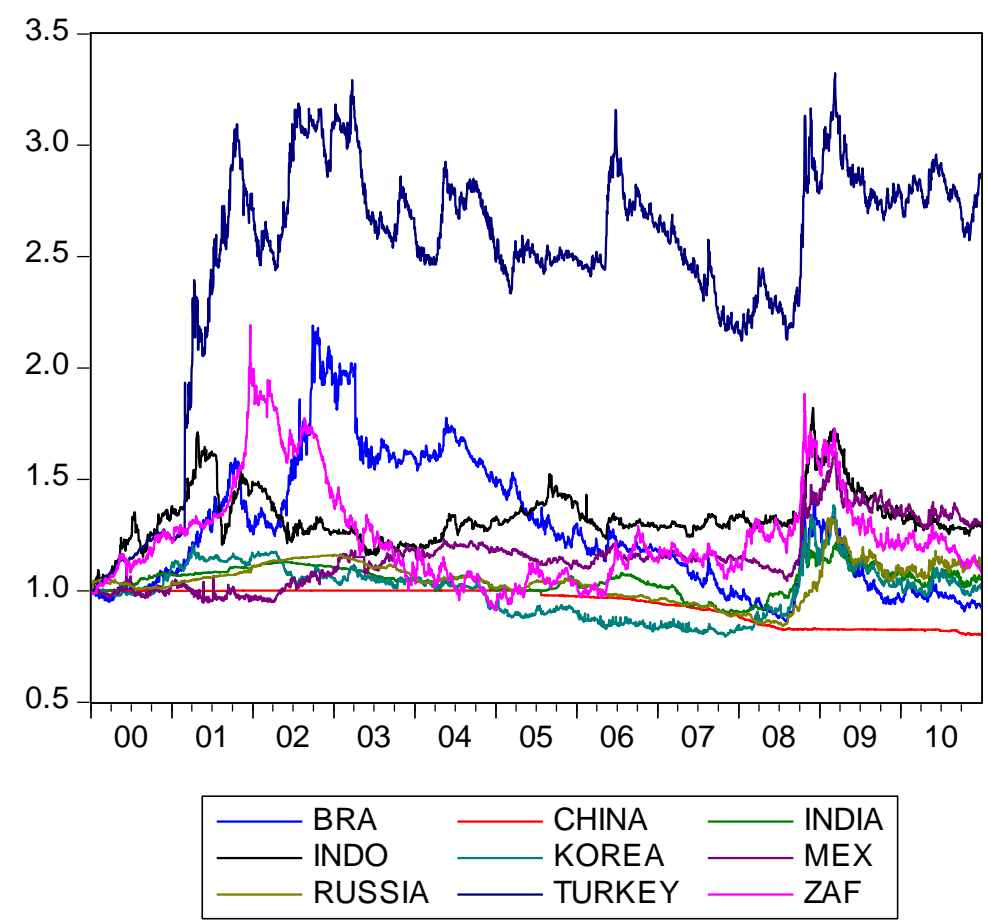

Table 1: ADF Unit Root Test

\begin{tabular}{|c|c|cc|cc|}
\hline \multirow{2}{*}{ COUNTRIES } & \multirow{2}{*}{ VARIABLES } & \multicolumn{2}{|c|}{ Constant } & \multicolumn{2}{c|}{ Constant\&Trend } \\
\cline { 2 - 6 } & & t stat & p value & t stat & p value \\
\hline \multirow{2}{*}{ CHINA } & SIO & -5.177688 & 0.0000 & -5.634018 & 0.0000 \\
\cline { 2 - 6 } & IP \% change & -12.68300 & 0.0000 & -12.63307 & 0.0000 \\
\cline { 2 - 6 } & IP \% change & -8.859375 & 0.0000 & -8.847770 & 0.0000 \\
\hline \multirow{2}{*}{ INDIA } & SIO & -4.826105 & 0.0001 & -8.402658 & 0.0000 \\
\cline { 2 - 6 } & IP \% change & -12.81005 & 0.0000 & -13.21371 & 0.0000 \\
\hline \multirow{2}{*}{ KOREA } & SIO & -4.416906 & 0.0004 & -4.672478 & 0.0012 \\
\cline { 2 - 6 } & IP \% change & -5.902410 & 0.0000 & -5.878906 & 0.0000 \\
\cline { 2 - 6 } & IP \% change & -10.02967 & 0.0000 & -10.04388 & 0.0000 \\
\hline \multirow{2}{*}{ MEXICO } & SIO & -4.573076 & 0.0002 & -4.529760 & 0.0020 \\
\cline { 2 - 6 } & IP \% change & -12.40312 & 0.0000 & -12.37070 & 0.0000 \\
\hline \multirow{2}{*}{ RUSSIA } & SIO & -4.023726 & 0.0018 & -7.429101 & 0.0000 \\
\cline { 2 - 6 } & IP \% change & -12.99133 & 0.0000 & -12.96435 & 0.0000 \\
\hline \multirow{2}{*}{ TURKEY } & SIO & -5.212453 & 0.0000 & -5.258634 & 0.0001 \\
\hline & & & & & 0.000000 \\
\hline
\end{tabular}




\begin{tabular}{|l|c|cc|cc|}
\hline & IP \% change & -23.67793 & 0.0000 & -23.59197 & 0.0000 \\
\hline \multirow{2}{*}{ S. AFRICA } & SIO & -4.706892 & 0.0001 & -4.750631 & 0.0009 \\
\cline { 2 - 6 } & IP \% change & -16.57014 & 0.0000 & -16.60784 & 0.0000 \\
\hline
\end{tabular}

Table 2: Breitung-Candelon (2006) causality tests in frequency domain

\begin{tabular}{|c|c|c|c|}
\hline COUNTRIES & Frequency: & $\begin{array}{c}0<\omega<0.35 \\
\text { Period: higher than } 18 \\
\text { months }\end{array}$ & $\begin{array}{c}0.35<\omega<\pi \\
\text { Period: } 2 \text { months to } 18 \\
\text { months }\end{array}$ \\
\hline \multirow{2}{*}{ BRAZIL } & IP causes $\mathrm{SIO}$ & $\mathrm{NO}$ & $\mathrm{NO}$ \\
\hline & SIO causes IP & $\underline{\text { YES }}$ & NO (but yes up to $\omega=0.9$ ) \\
\hline \multirow{2}{*}{ CHINA } & IP causes SIO & NO & NO \\
\hline & SIO causes IP & $\underline{\mathbf{Y E S}}$ & YES \\
\hline \multirow{2}{*}{ INDIA } & IP causes $\mathrm{SIO}$ & $\mathrm{NO}$ & $\mathrm{NO}$ \\
\hline & SIO causes IP & $\mathrm{NO}$ & $\mathrm{NO}$ \\
\hline \multirow{2}{*}{ INDONESIA } & IP causes SIO & $\mathrm{NO}$ & $\mathrm{NO}$ \\
\hline & SIO causes IP & $\underline{\mathbf{Y E S}}$ & NO (but yes up to $\omega=0.4$ ) \\
\hline \multirow{2}{*}{ KOREA } & IP causes SIO & $\mathrm{NO}$ & $\mathrm{NO}$ \\
\hline & SIO causes IP & $\underline{\text { YES }}$ & NO (but yes up to $\omega=0.9$ ) \\
\hline \multirow{2}{*}{ MEXICO } & IP causes SIO & $\mathrm{NO}$ & $\mathrm{NO}$ \\
\hline & SIO causes IP & $\underline{\text { YES }}$ & NO (but yes up to $\omega=1.2$ ) \\
\hline \multirow{2}{*}{ RUSSIA } & IP causes SIO & NO & NO \\
\hline & SIO causes IP & NO & NO (but yes after $\omega=1.6$ ) \\
\hline
\end{tabular}




\begin{tabular}{|c|c|c|c|}
\hline \multirow{2}{*}{ TURKEY } & IP causes SIO & NO & NO \\
\cline { 2 - 4 } & SIO causes IP & $\underline{\text { YES }}$ & NO (but yes up to $\omega=0.8$ ) \\
\hline \multirow{2}{*}{ S. AFRICA } & IP causes SIO & NO & NO \\
\cline { 2 - 4 } & SIO causes IP & $\underline{\text { YES }}$ & NO \\
\hline
\end{tabular}

Lag is taken as 3 or 4 in all country cases. $\omega$ denotes frequency. $\pi$ is the pi number which denotes the maximum level of frequency.

Figure 3: Breitung-Candelon (2006) causality tests in frequency domain: BRAZIL SIO index $\rightarrow$ GROWTH

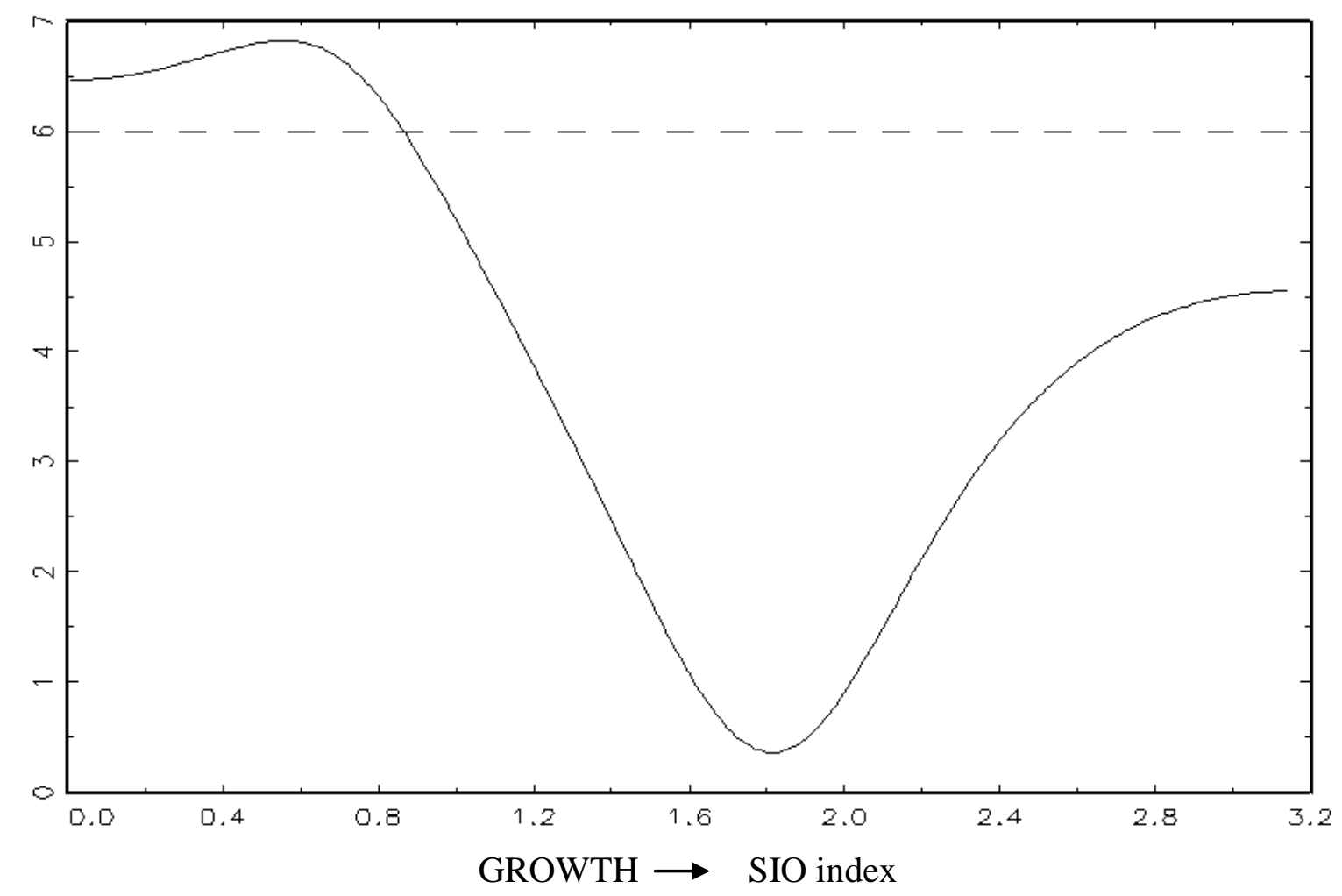




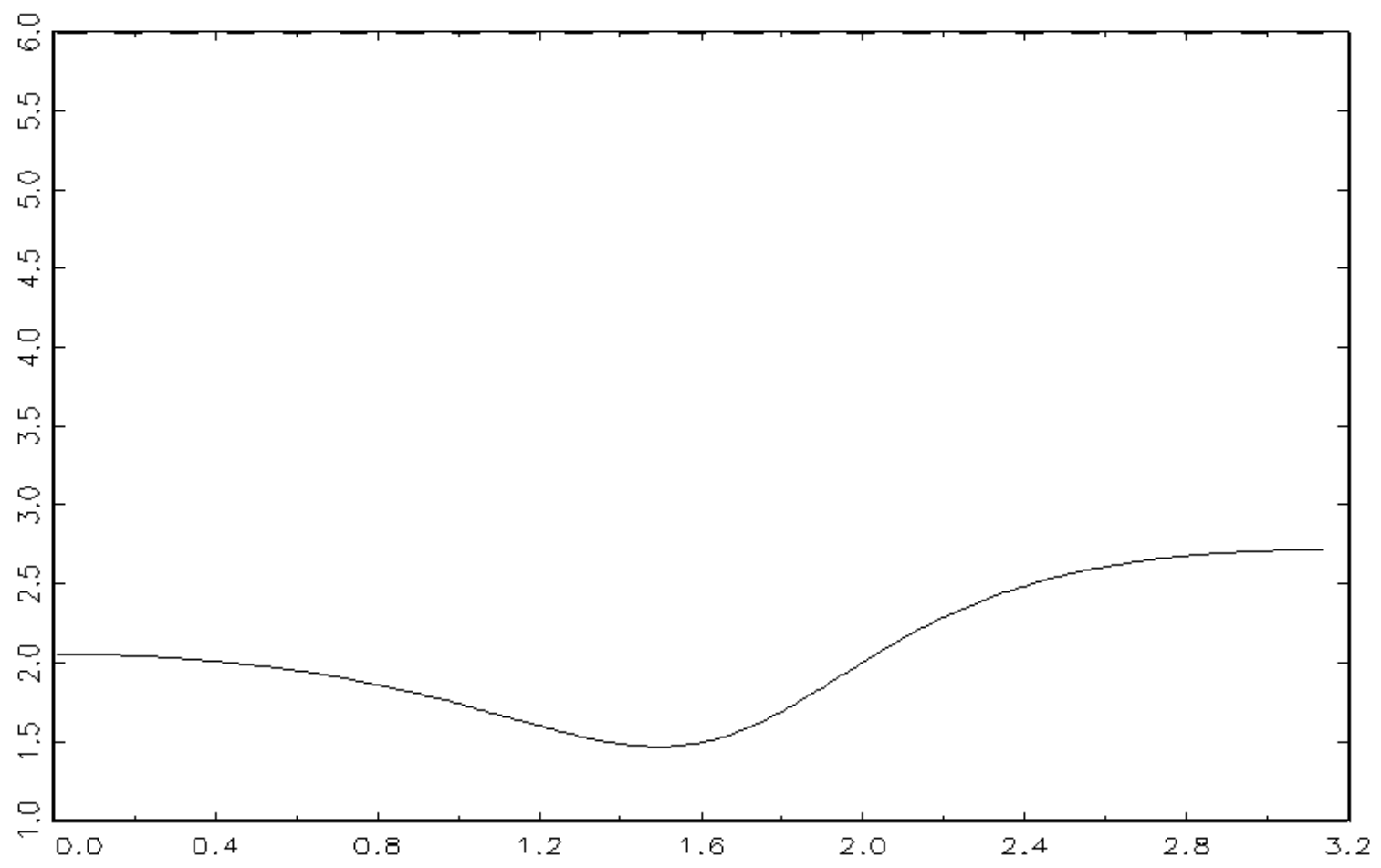

Figure 4: Breitung-Candelon (2006) causality tests in frequency domain: CHINA $\mathrm{SIO}$ index $\rightarrow$ GROWTH

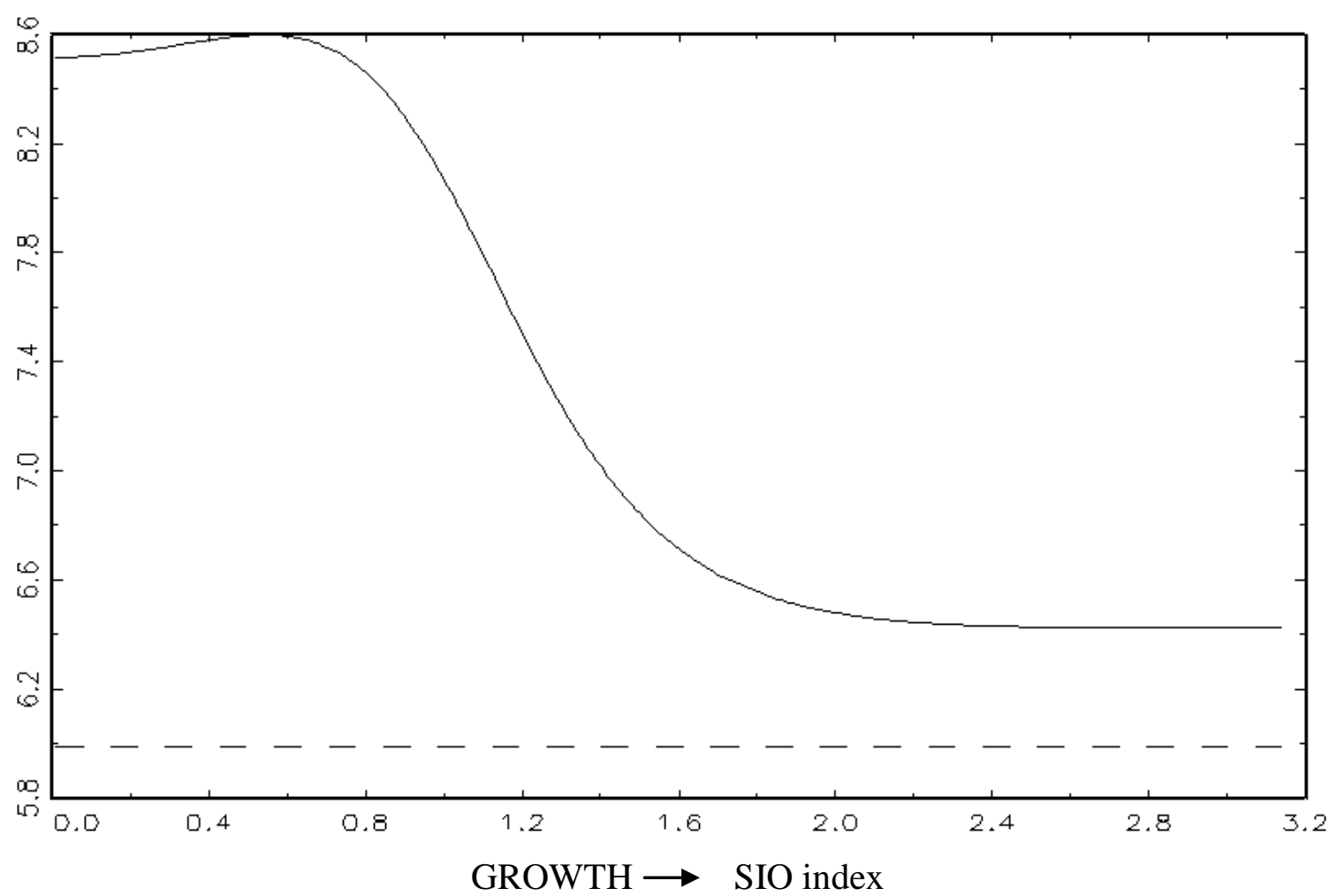




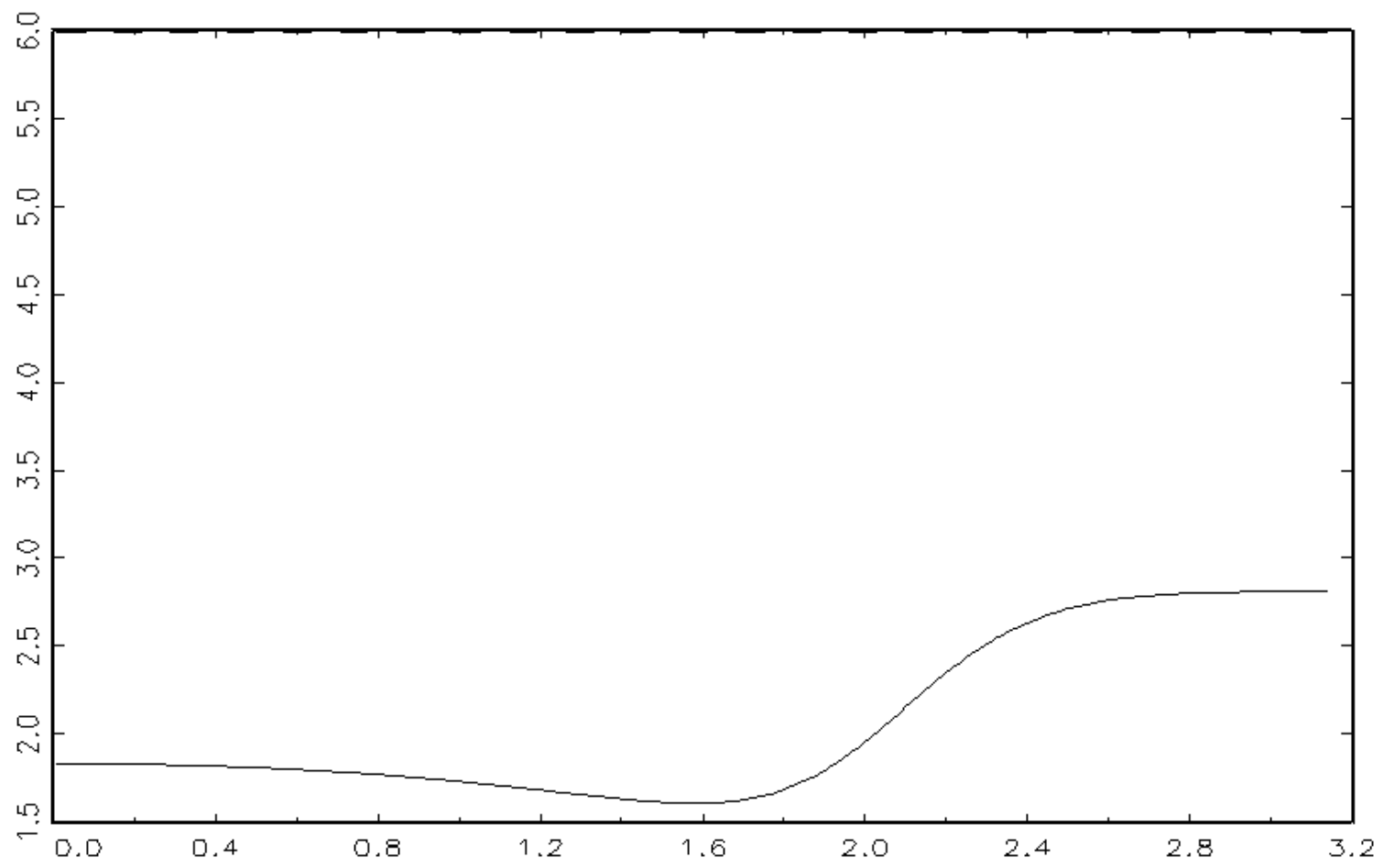

Figure 5: Breitung-Candelon (2006) causality tests in frequency domain: INDIA SIO index $\rightarrow$ GROWTH

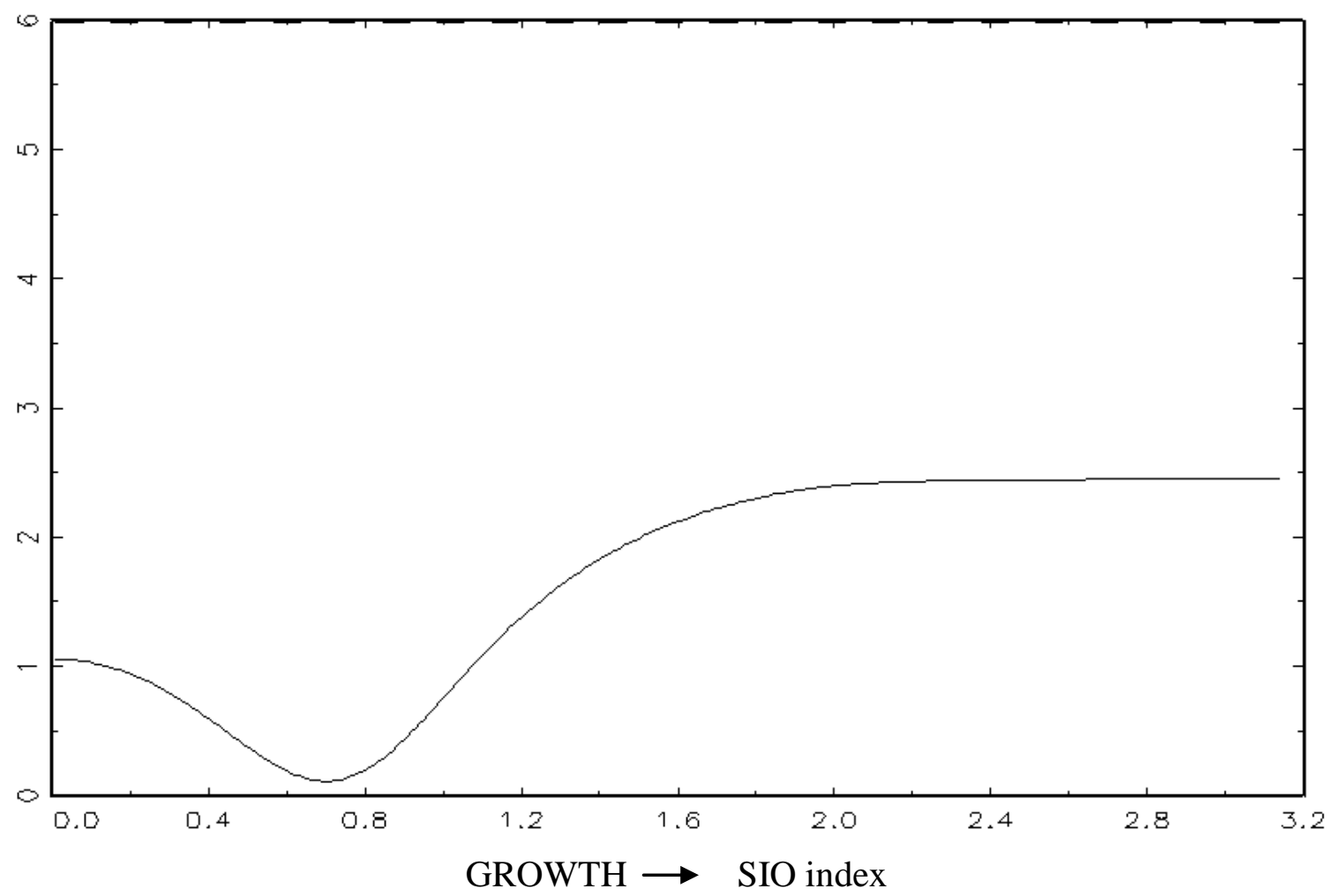




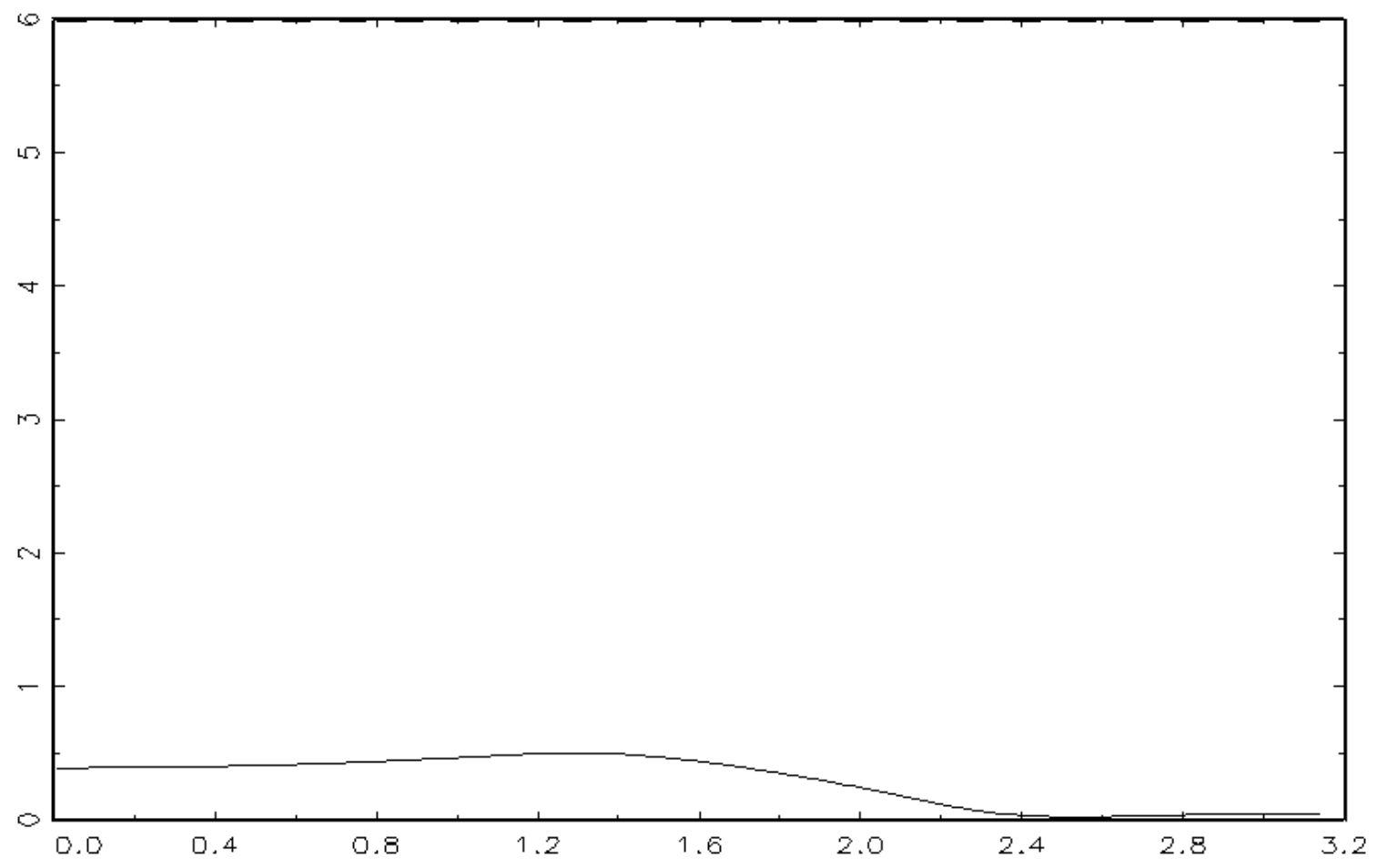

Figure 6: Breitung-Candelon (2006) causality tests in frequency domain: INDONESIA

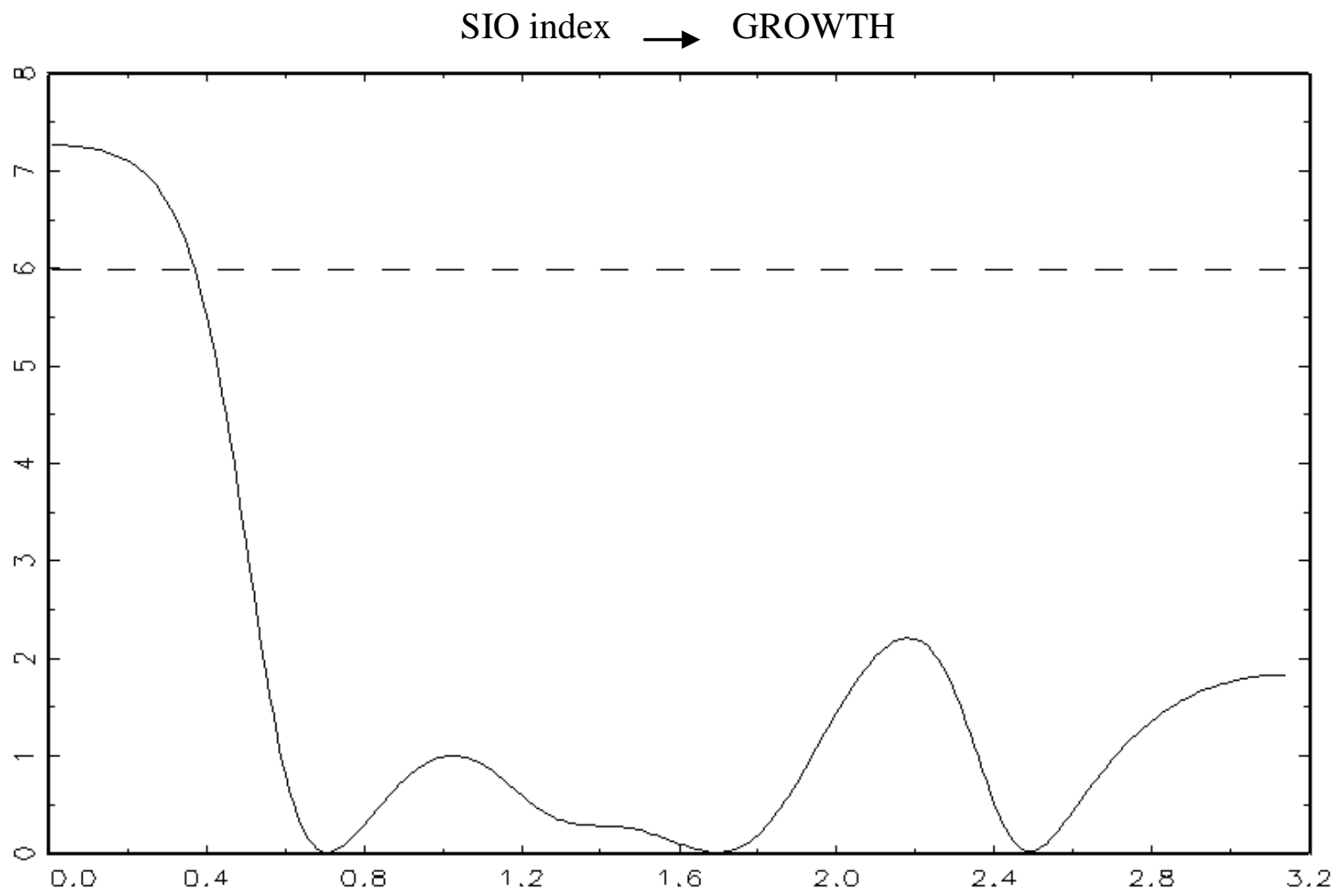




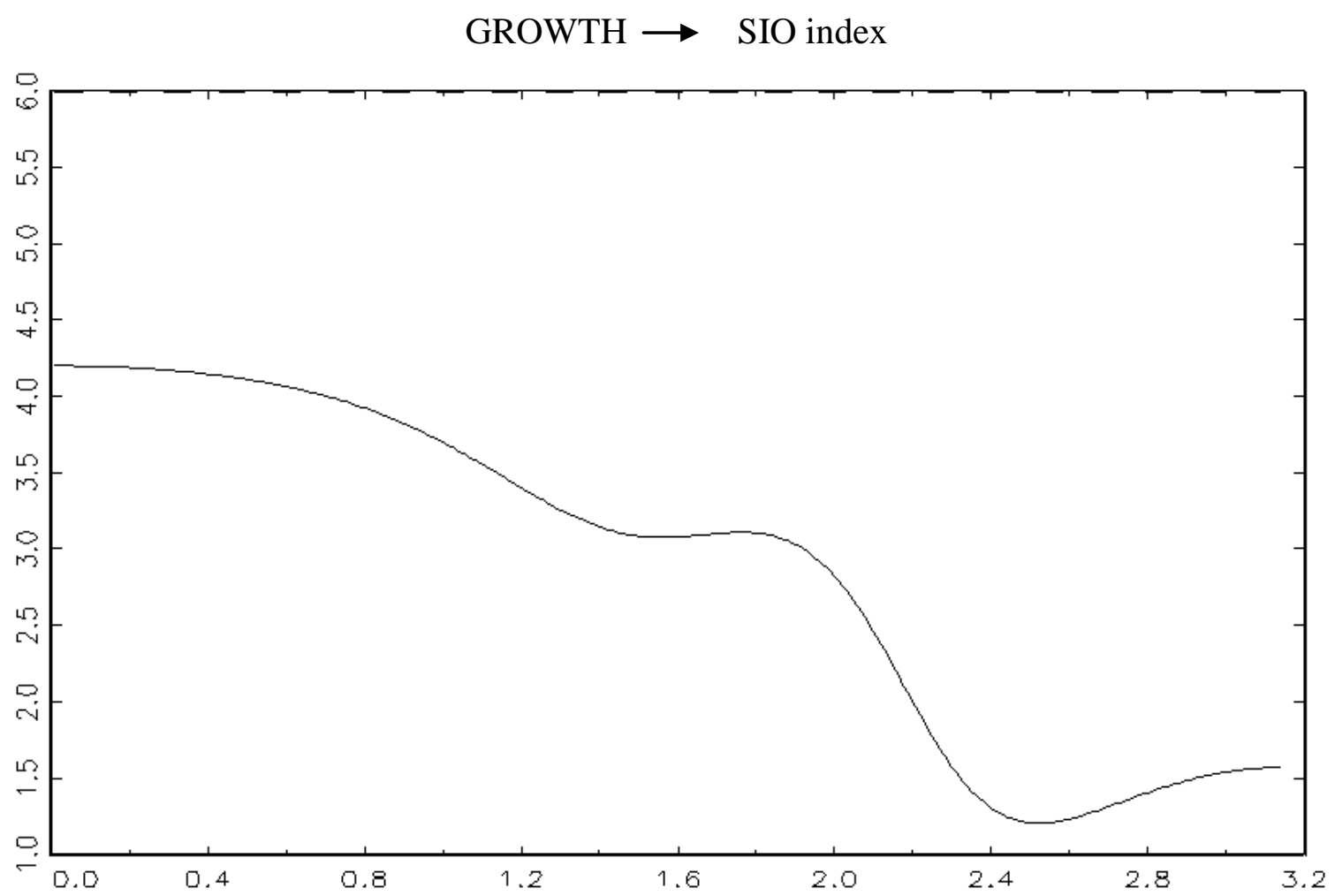

Figure 7: Breitung-Candelon (2006) causality tests in frequency domain: KOREA $\mathrm{SIO}$ index $\rightarrow$ GROWTH

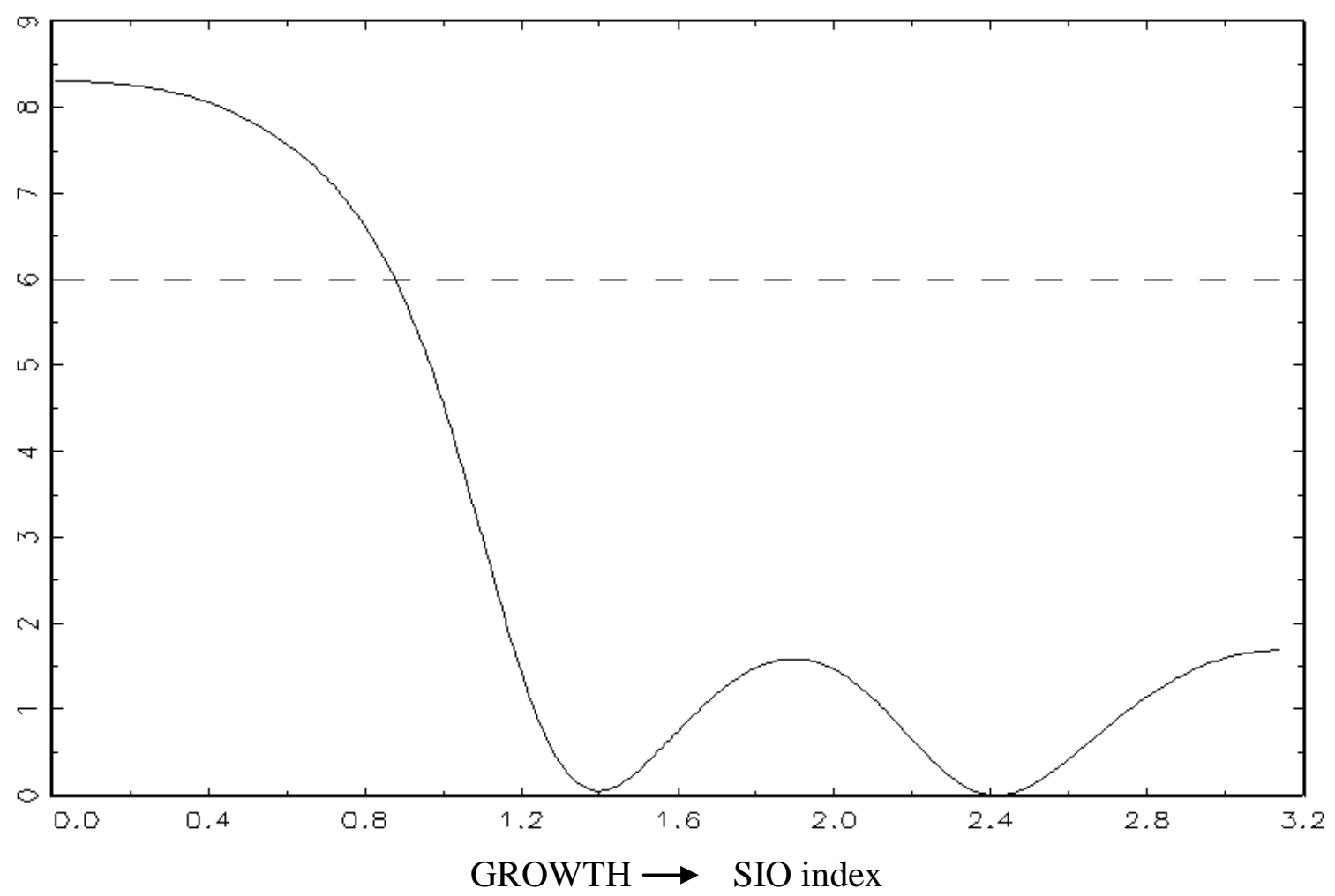




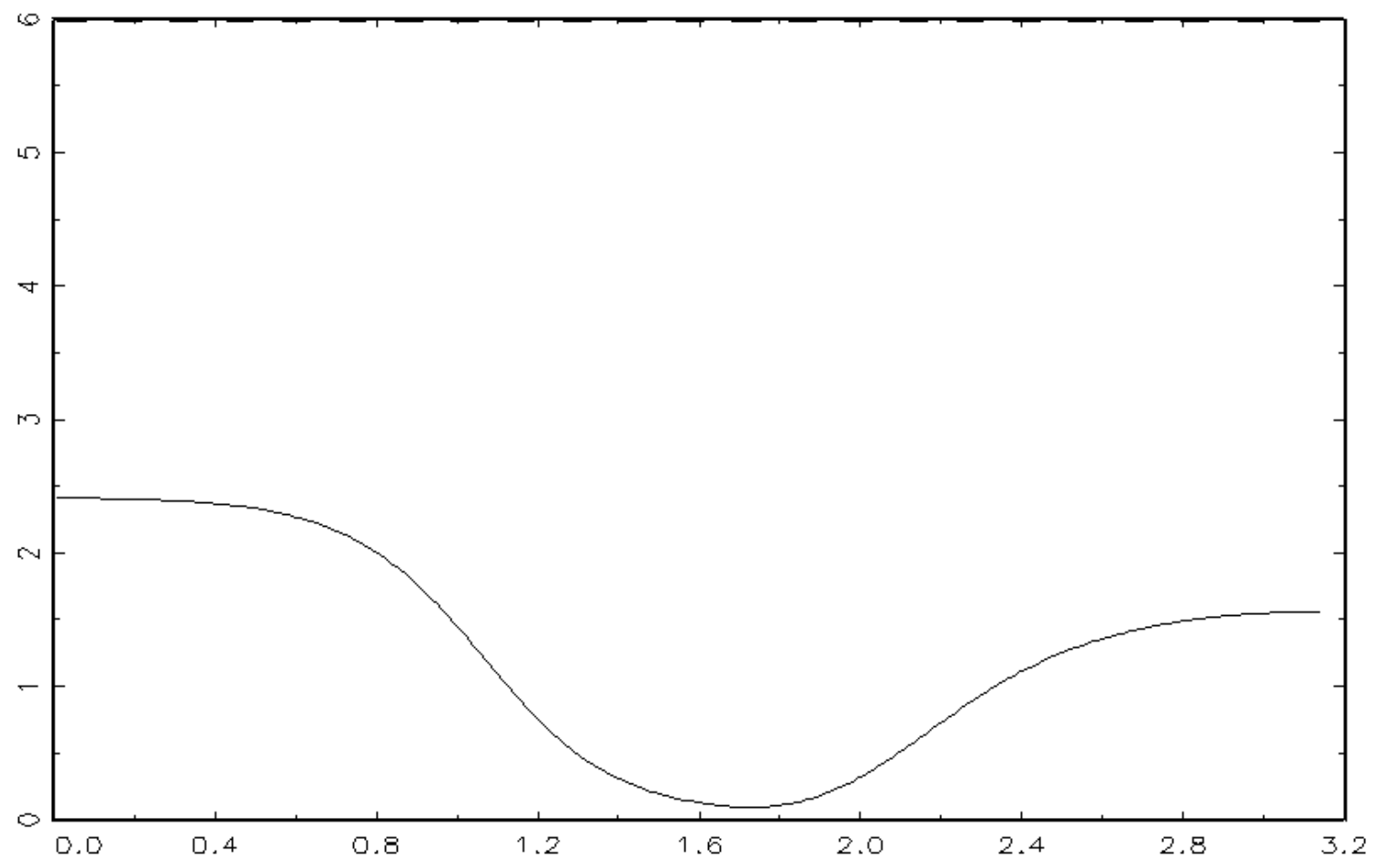

Figure 8: Breitung-Candelon (2006) causality tests in frequency domain: MEXICO SIO index $\rightarrow$ GROWTH

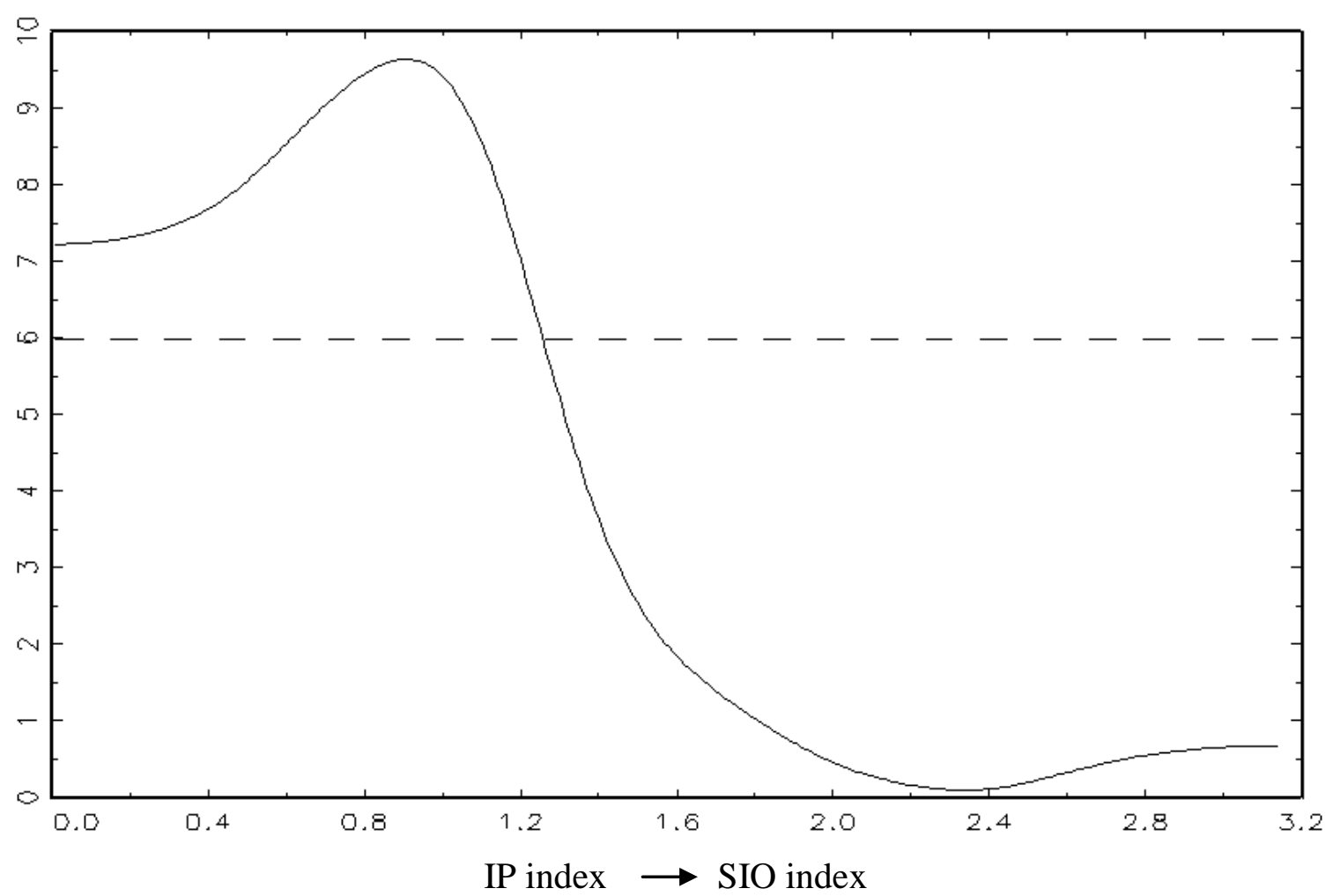




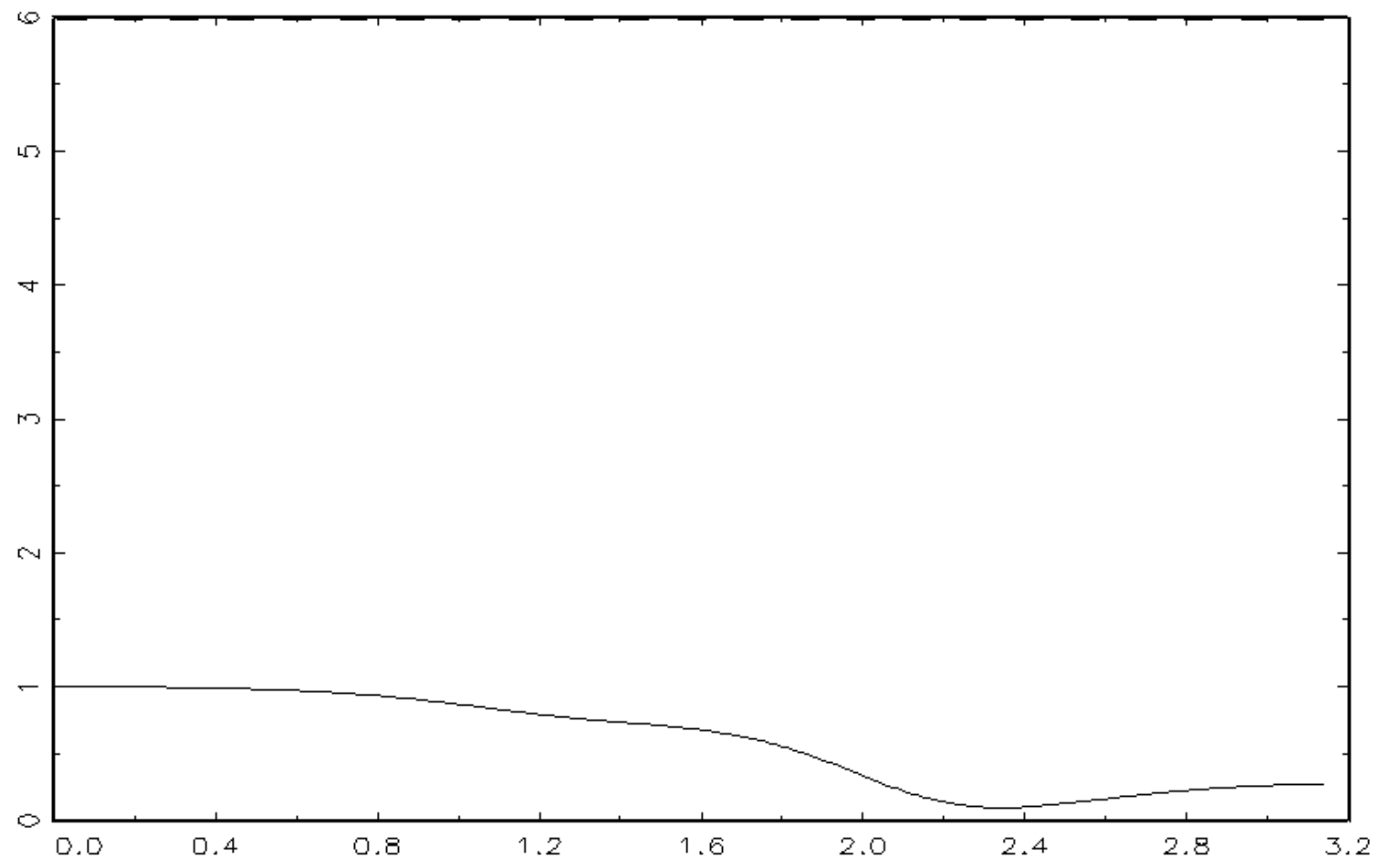

Figure 9: Breitung-Candelon (2006) causality tests in frequency domain: RUSSIA

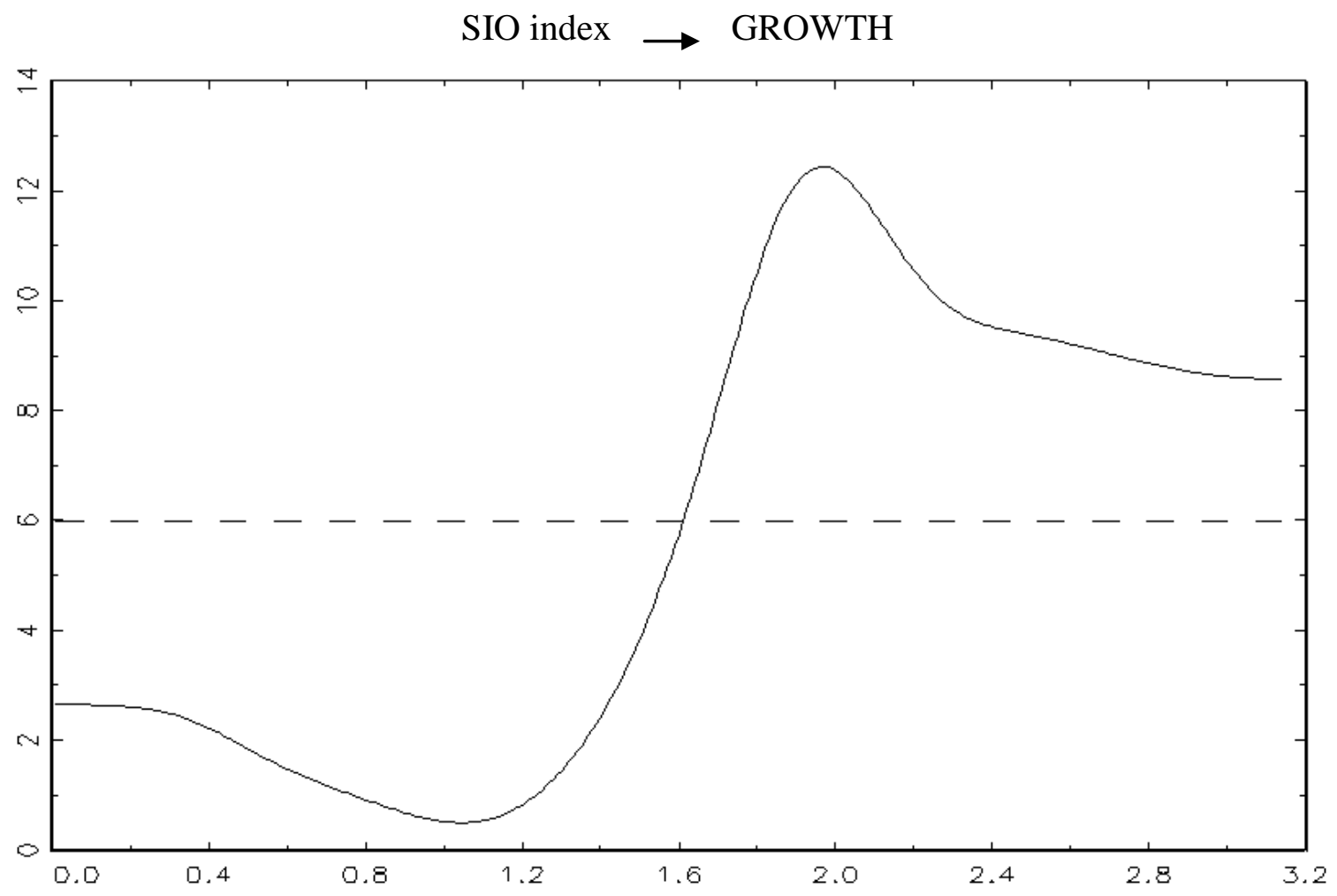


GROWTH $\rightarrow$ SIO index

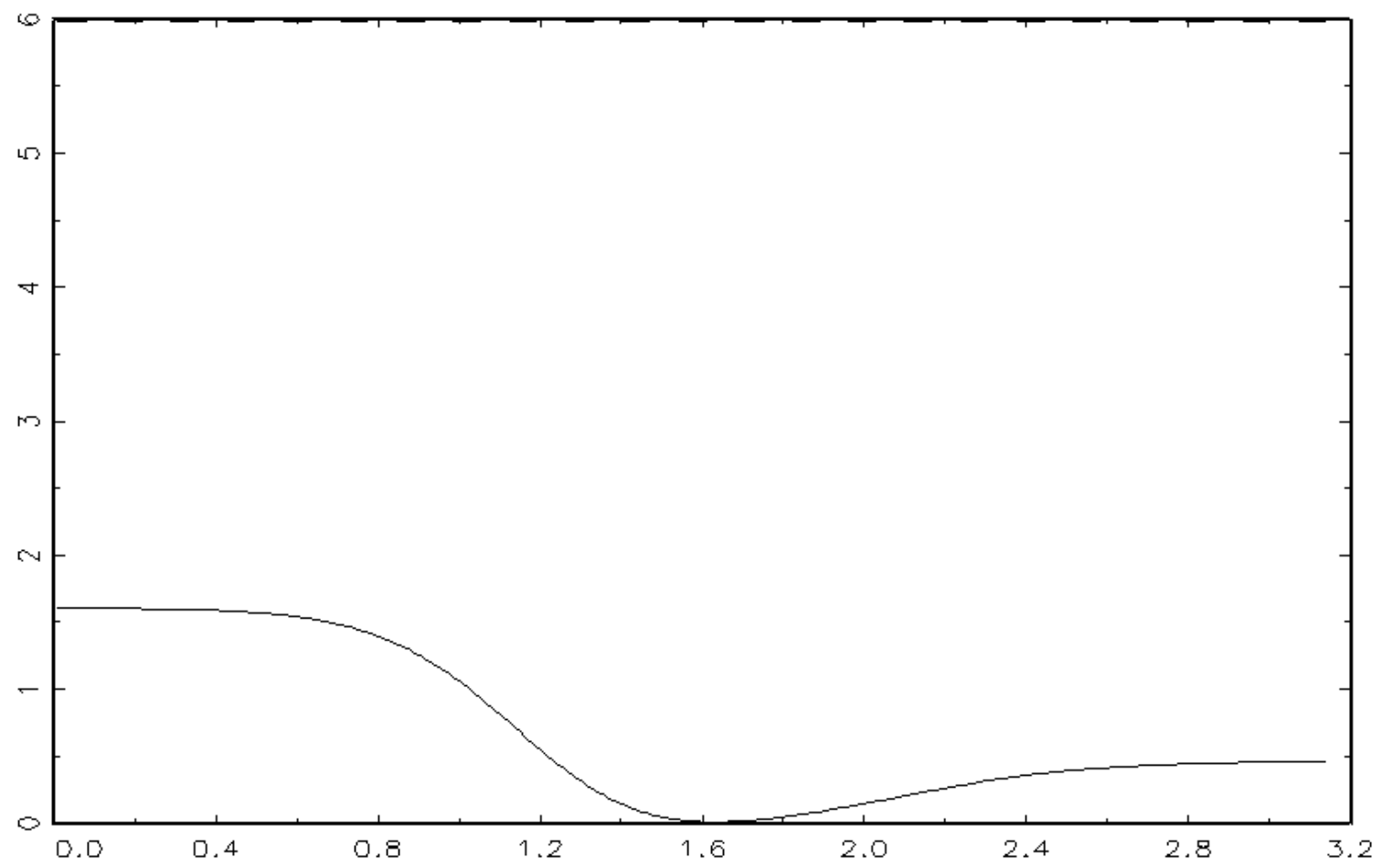

Figure 10: Breitung-Candelon (2006) causality tests in frequency domain: TURKEY $\mathrm{SIO}$ index $\rightarrow$ GROWTH

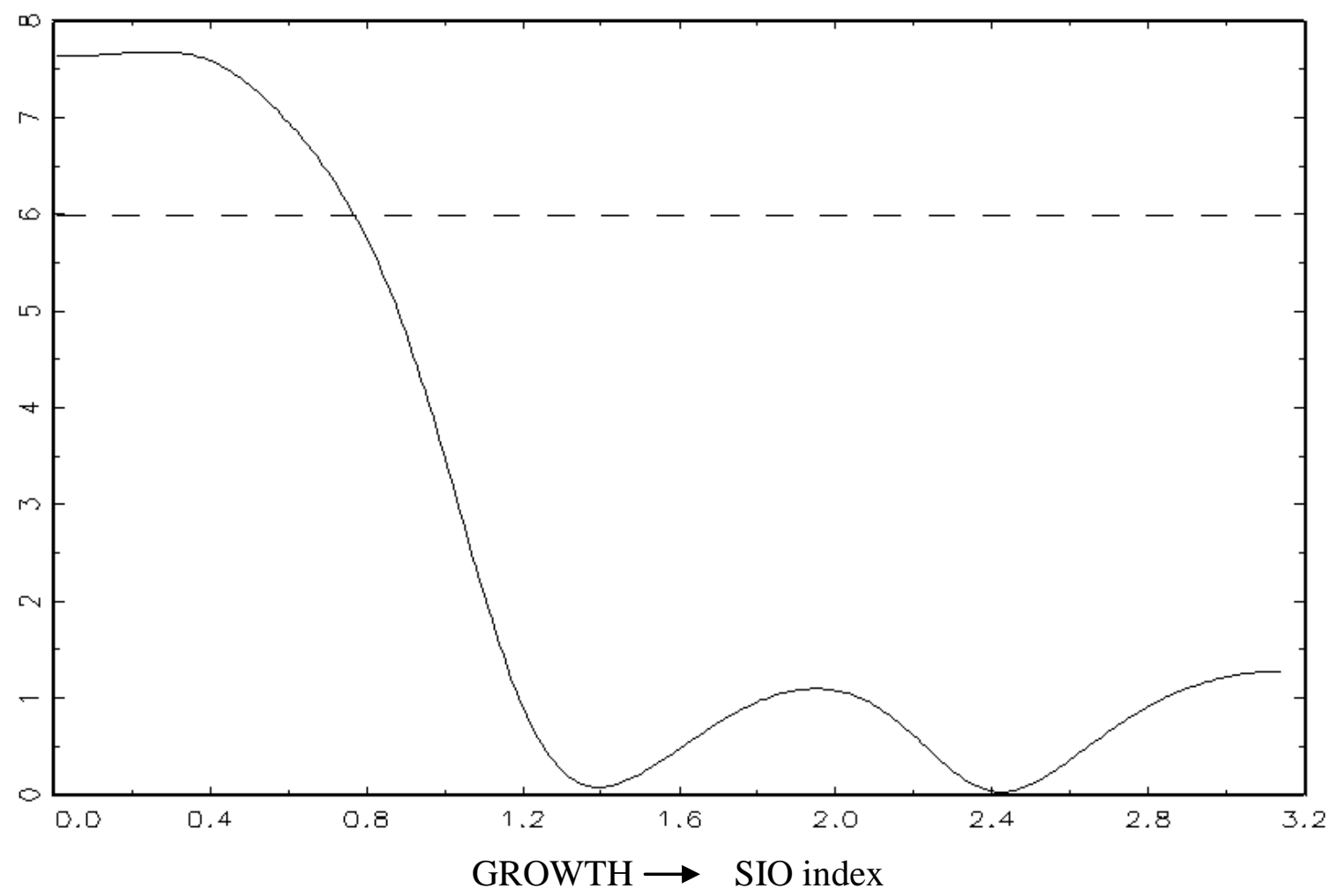




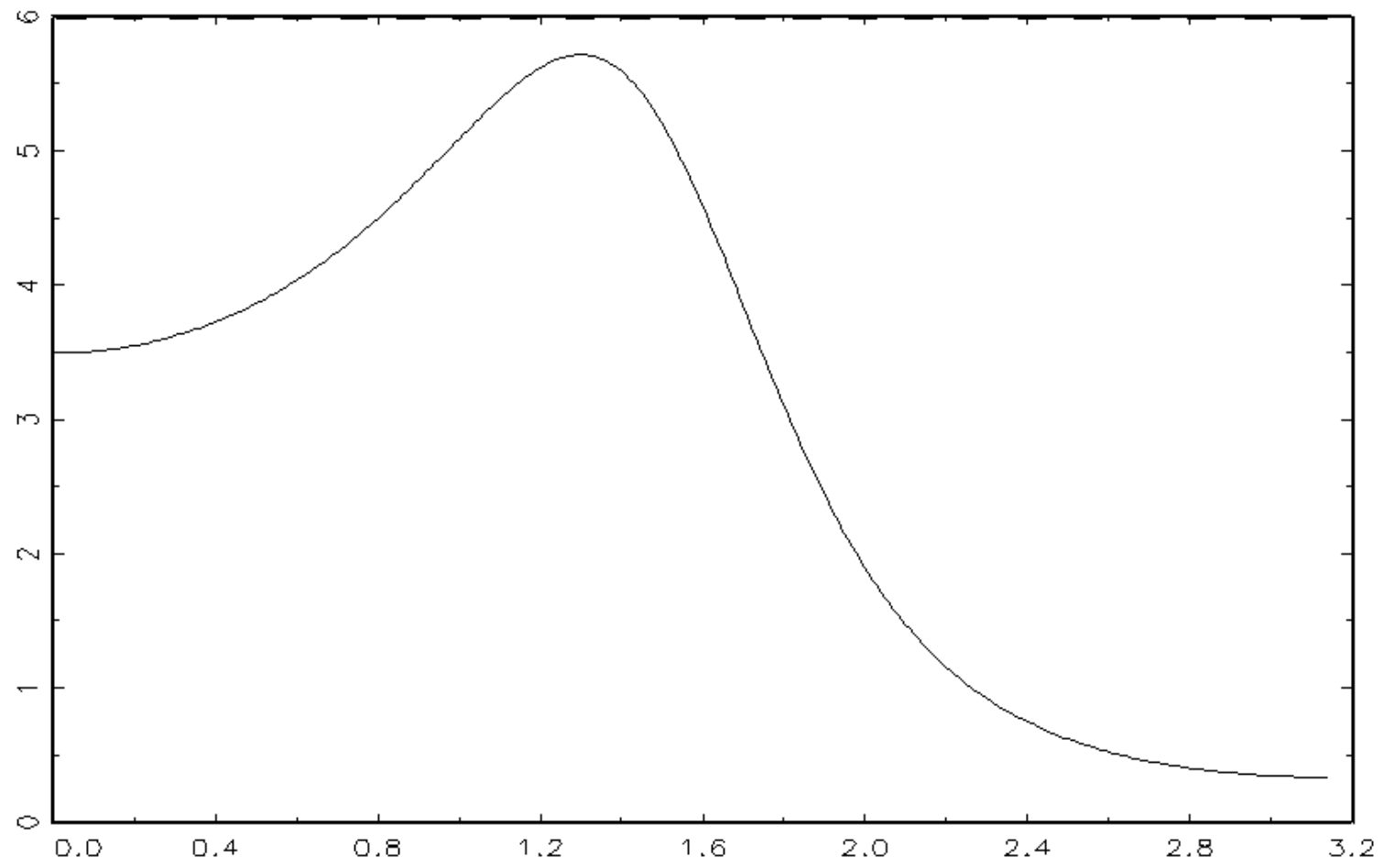

Figure 11: Breitung-Candelon (2006) causality tests in frequency domain: SOUTH AFRICA

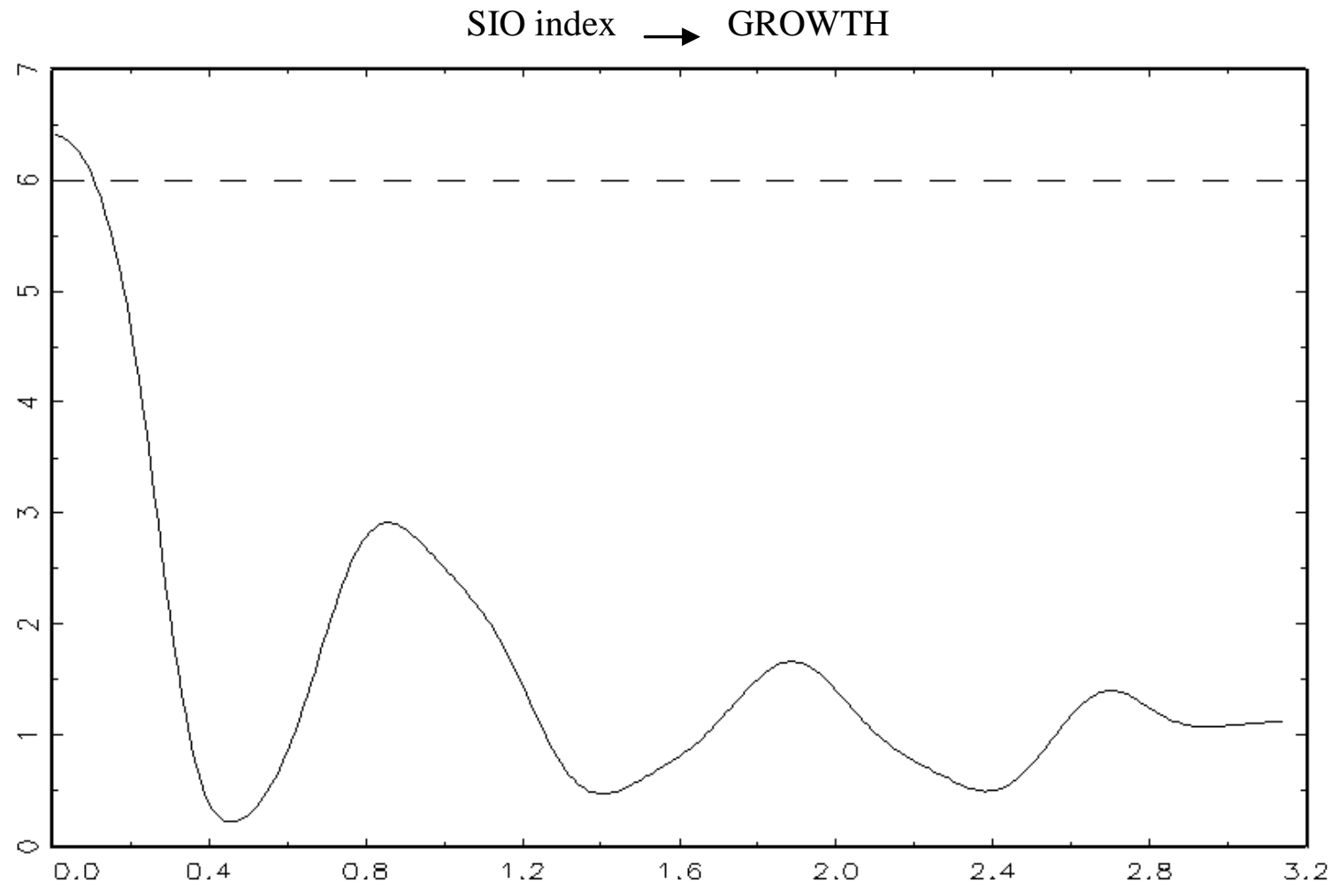


GROWTH $\rightarrow$ SIO index

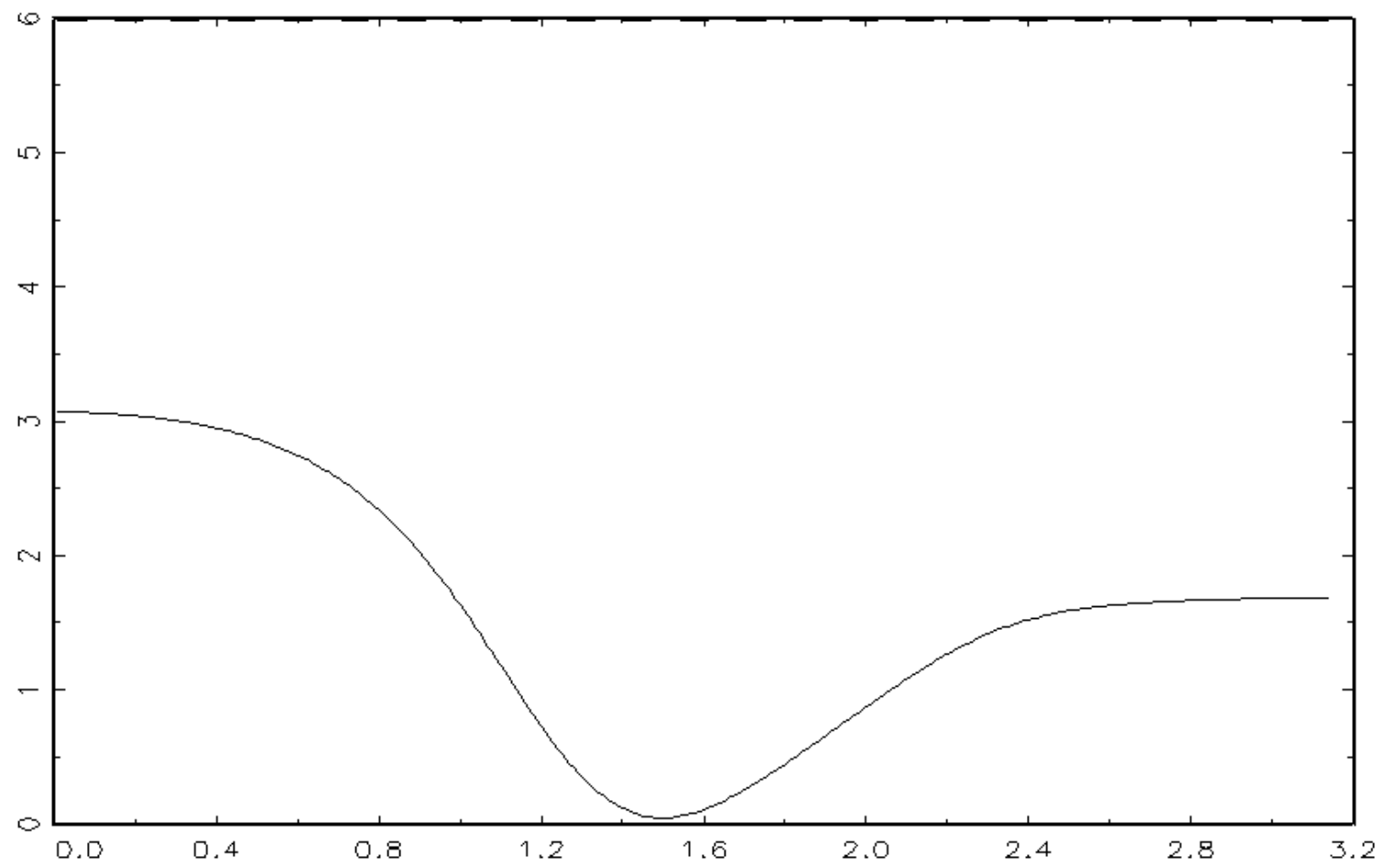

